\title{
KUTTAB DALAM LINTASAN SEJARAH : DARI MASA PEMBINAAN HINGGA KEJAYAAN PENDIDIKAN ISLAM (570 M-1258 M)
}

\author{
Mahfud Ifendi \\ Sekolah Tinggi Agama Islam Sangatta Kutai Timur \\ Email:mahfudzifindi@gmail.com
}

\begin{abstract}
Abstrak
Kuttab merupakan sebuah lembaga pendidikan Islam yang pernah muncul di awal peradaban Islam. Sebenarnya keberadaannya telah diketahui sejak pra Islam, namun dalam perkembangannya tidak begitu berjalan dengan baik. Untuk mendeskripsikan kuttab dalam beberapa waktu, dalam artikel ini data dikumpulkan dari berbagai literatur seperti artikel ilmiah, buku-buku sejarah dan hasil penelitian. Adapun analisis datanya dengan menggunakan analisis data Miles and Hubberman. Dalam kesimpulannya artikel ini menunjukkan bahwa kuttab dalam lintasan sejaran Islam telah mengalami beberapa pembaruan, baik dari segi pengelolaan, pembiayaan maupun kurikulumnya. Dari konten kurikulum, terdapat beberapa pembaharuan yang mencolok yang dapat kita amati di setiap periodenya. Mulai dari yang paling sederhana mengajarkan tentang baca-tulis kepada anakanak muslim hingga di tingkat menengah dan tinggi terdapat pelajaran balaghah, nahwu, sharaf, mantiq, tafsir, fiqih, ushul fiqh, kedokteran, kimia, ilmu hewan dan lain-lain. Terkait dengan pembiayaannya, ada yang sukarela, dari pajak tanah dan secara resmi diambil dari anggaraan belanja negara.
\end{abstract}

Kata kunci: Kuttab, lembaga pendidikan Islam

\begin{abstract}
Kuttab is an Islamic educational institution that appeared at the beginning of Islamic civilization. Actually, its existence has been known since pre-Islamic time, but its development it has not gone well. In order to describe the kuttab in some time, in this article data were collected from various works of literature such as scientific articles, historical books, and research results. The data analysis used data analysis by Miles and Hubberman. In conclusion, this article shows that kuttab in the trajectory of Islamic history has undergone several reforms, both in terms of management, financing, and curriculum. From the curriculum content, there are several striking updates that we can observe in each period. Starting from the simplest teaching about reading and writing to Muslim children to the middle and high levels there are lessons on balaghah, nahwu, sharaf, mantiq, tafsir, fiqih, ushul fiqh, medicine, chemistry, zoology, and others. Regarding financing, some are voluntary, from land taxes and officially taken from the state budget.
\end{abstract}

Keywords: Kuttab, Islamic Educational Institutions 


\section{A. PENDAHULUAN}

Dalam sejarah Islam, sejak Nabi menerima wahyu dari Allah SWT maka mulai saat itu pendidikan dan pengajaran dimulai. Mula-mula ketika Nabi masih tinggal di kota Makkah, maka institusi atau lembaga pendidikan yang dijadikan sebagai wadah atau tempat untuk mengajarkan wahyu Allah SWT adalah di Daar al-Arqam. Seiring dengan berjalannya waktu, ketika Nabi hijrah ke kota Madinah dan terlepas dari tekanan kafir Quraisy, maka pertumbuhan dan perkembangan lembaga pendidikan Islam semakin variatif dan terbuka untuk umum (Arifin, 2014, p. 80). Jika dilihat dari historisnya, maka perkembangan pendidikan Islam baik secara kelembagaan, pendidik, peserta didik, metode, maupun kurikulumnya tentu sangatlah panjang dan beragam (Darwis, 2010, p. 5).

Menarik untuk diamati bahwa dengan munculnya berbagai lembaga pendidikan Islam dari masa pembinaan sampai dengan puncak kejayaannya, tentu hal ini dapat kita ambil sebuah kesimpulan bahwa ini merupakan salah satu indikator kemajuan terbesar umat Islam. Artinya dengan banyaknya lembaga pendidikan yang ada, akan menambah khazanah keIslaman tentang ragam dan lembaga pendidikan yang digunakan untuk mengantarkan umat Islam ke puncak peradaban. Dari perkembangan Pendidikan Islam saat itu tentu banyak melahirkan para tokohtokoh ilmuan yang ahli di berbagai rumpun keilmuan.

Lembaga pendidikan itu sendiri berarti sebuah tempat dengan kondisi tertentu yang tujuan utamanya adalah untuk menyelenggarakan proses belajar-mengajar, baik secara terstruktur, sistematis dan berjenjang sebagaimana kondisi saat ini ataupun secara tradisi yang telah diciptakan sebelumnya dengan segala sesuatu yang masih sangat sederhana (Roqib, 2009, p. 121). Hal yang sama juga disampaikan oleh Fatah Yasin mengatakan bahwa lembaga pendidikan adalah bentuk wadah organisasi yang berfungsi sebagai pengembangan kegiatan pendidikan Islam (Yasin, 2008, p. 201). Menambahkan keterangan terkait dengan arti Lembaga Pendidikan islam, lembaga pendidikan itu mengandung pengertian konkret berupa sarana pra sarana dan juga pengertian yang abstrak, dengan adanya norma-norma dan peraturan-peraturan tertentu, serta penanggung jawab pendidikan itu sendiri (Andriani, 2016, p. 327).

Dalam artikel ini tidak mendiskusikan tentang lengkap atau tidaknya sebuah saranaprasarana pendidikan yang kemudian dalam hal ini dapat berimbas terhadap pemaknaan sebuah lembaga pendidikan. Melainkan jauh daripada itu, mari kita letakkan pada pemahaman yang mendasar tentang lembaga pendidikan yaitu sebuah tempat yang dijadikan sebagai wadah kegiatan belajar-mengajar (Ifendi, 2020b, p. 68). Hal senada disampaikan oleh Nyayu Soraya yang mengatakan bahwa lembaga pendidikan Islam adalah sebuah wadah atau tempat berlangsungnya proses pendidikan Islam (Soraya, 2016, p. 251).

Di masa pembinaan pendidikan Islam pada periode Nabi, maka mulai muncul beberapa lembaga pendidikan Islam seperti Daar al-Arqam yang merupakna sebuah rumah sahabat yang kemudian dijadikan sebagai pusat pembelajaran umat islam oleh Nabi Muhammad SAW, meskipun dalam penyelenggarannya masih dilakukan secara sembunyi-sembunyi. Berikutnya ada masjid yang eksistensinya terlihat Ketika Nabi dan para sahabat hijrah dari Makkah menuju Madinah. Hal pertama yang dilakukan oleh Nabi Ketika pindah ke Madinah adalah mendirikan sebuah masjid sebagai tempat ibadah dan juga sebagai pusat kegiatan lainnya seperti tempat belajar. Kemudian ada kuttab yang dalam sejarahnya sudah pernah ada sebelum Islam datang, namun perkembangannya sangat lamban dan tidak banyak dikenal orang, serta Lembaga 
Pendidikan Islam yang bernama suffah, biasanya didirikan di sebelah masjid (Zainal Aqib, 2014, p. 65). Agar kajian pada artikel ini tidak melebar dan ingin lebih fokus pada satu topik, maka dalam artikel ini akan dibahas tentang lembaga pendidikan yang bernama kuttab, dari awal periode Nabi selama di Madinah sampai dengan masa kejayaan pendidikan Islam pada periode dinasti Abbasiyah. Dari sekian periode tentunya kuttab memiliki karakteristik yang berbedabeda, sehingga menarik untuk dianalis lebih dalam (Laisa, 2020, p. 98). Mengapa dimulai dari masa pembinaan dan berakhir pada masa puncak kejayaan? Jawabannya tak lain dan tak bukan adalah untuk menganalisa perkembangan kuttab dari awal kemunculannya hingga sampai berkembang pesat di masa kejayaan Islam. Dipungkiri atau tidak bahwa dari sektor pendidikan inilah yang memberikan sumbangsih ide, pemikiran dan kontribusi serta melahirkan para ulama dan ilmuan terkemuka sehingga Islam dapat berada pada puncak kejayaannya. Selain itu, pentingnya pembahasan ini adalah untuk menggalakkan kembali, mengamati dan mengadopsi tentang sistem, kurikulum, metode dan pembiayaannya di era dewasa ini untuk menjadi sebuah lembaga pendidikan dasar yang adaptif dengan segala bentuk perubahan.

Kita semua tidak bisa menutup mata bahwa sesungguhnya Lembaga Pendidikan Islam yang telah ada berdiri lama dan apa yang dibangun dewasa ini telah memiliki banyak tantangannya. Tantangan itu bisa saja muncul dari bidang politik, ekonomi, social, ilmu pengetahuan dan teknologi, system nilai, budaya dan lain sebagainya (Hawi, 2017, p. 147).

\section{B. METODE PENELITIAN}

Tipe riset ini ialah riset kualitatif. Sesuai dengan obyek kajian artikel ini, sehingga tipe riset ini tercantum dalam jenis riset kepustakaan (library research). Bagi Kaelan, dalam riset kepustakaan kadangkala mempunyai deskriptif serta pula mempunyai karakteristik historis (Kaelan, 2010, p. 66). Metode pengumpulan informasi, dalam perihal ini penulis melaksanakan analisis dari berbagai literatur yang ada yang berkaitan dengan lembaga pendidikan Islam sejak masa pendidikan Islam Nabi di Madinah hingga era dinasti Abbasiyah, khususnya yang berkaitan dengan kuttab. Literatur yang digunakan dalam penulisan artikel ini adalah diambil dari artikel-artikel ilmiah. Buku-buku referensi dan berbagi informasi lainnya yang dapat digunakan sebagai data pendukung. Berikutnya penyusunan ini ditelaah dengan memakai model analisis interaktif Milles and Huberman, dengan alur reduksi informasi, penataan informasi serta penarikan kesimpulan (Matthew B. Miles, A. Michael Huberman, 2014, p. 348).

\section{HASIL DAN PEMBAHASAN}

\section{Pengertian Kuttab}

Kuttab berasal dari kata kataba-yaktubu-kitaaban, yang artinya menulis. Kuttab biasanya diartikan sebagai tempat untuk belajar tulis-menulis atau sebuah tempat berlangsungnya kegiatan tulis-menulis untuk mempelajari sesuatu. Kuttab juga bisa diartikan sebagai lembaga pendidikan dasar yang mengajarkan tata cara membaca dan menulis bagi anak-anak dan remaja (Ramayulis, 2011, p. 78). Pengertian yang sama juga diungkapkan oleh Zainal Aqib yang menyatakan bahwa kuttab dilukiskan sebagai tempat untuk belajar membaca dan menulis bagi anak-anak (Zainal Aqib, 2014, p. 80).

Dikatakan bahwa awal kemuncullan kuttab sebagai lembaga pendidikan dasar ini adalah sejak lama dikenal oleh orang-orang Arab, bahkan telah dikenal dimasa jahiliah (Kodir, 2015, p. 
44). Hal ini sebagaimana diperkuat oleh Fathurrahman yang menyatakan bahwa kuttab telah ada sejak pra Islam sebagai lembaga tempat mengajarkan pengetahuan dan keterampilan membaca dan menulis (Fathurrahman, 2017, p. 65) Meskipun telah ada sejak lama, namun keberadaan kuttab ini tidak begitu banyak dikenal oleh orang-orang Arab. Hal ini dibuktikan bahwa dilihat dari perkembangannya terlihat lambat dan hanya ada 17 orang dari Quraisy yang pandai bacatulis (Kodir, 2015, p. 44). Di antara penduduk kota Makkah yang mula-mula belajar menulis huruf Arab ialah Sufyan ibnu Umaiyah ibnu Abdu Syams, dan Abu Qais ibnu Abd Manaf ibn Zuhroh ibn Kilat. Mereka mempelajarinya di negeri Hirah (Zuhairini, Moh. Kasiram, Abdul Ghofir, Tajdab, 2013, p. 89), yang belajar kepada Bisyr ibn `Abd al-Malik (Laisa, 2020, p. 97).

Kuttab didirikan oleh bangsa Arab sebelum Islam datang bertujuan untuk memberi pendidikan dan pengajaran berupa baca-tulis kepada anak-anak mereka (Abuddin Nata, 2014, p. 98). Diperkirakan kuttab mulai dikembangkan oleh pendatang ke tanah Arab, yang terdiri dari kaum Yahudi dan Nasrani dijadikan sebagai tempat untuk pengajaran kitab Taurat dan Injil, filsafat dan jadal (berdebat). Kegiatan ini dilakukan dengan tujuan untuk misi penyebaran agama Yahudi dan Kristen kepada pemeluk agama lain seperti pemeluk agama Majusi dan masyarakat Arab yang menyembah berhala (paganisme) (Kodir, 2015, p. 44).

Pada awal kemunculannya, proses belajar mengajar yang terdapat di dalam Lembaga Pendidikan ini adalah berbentuk halaqoh yakni para murid duduk memutar-mengelilingi seorang guru. Tentu system pembelajaran yang demikian ini merupakan sebuah system pembelajaran yang masih terbilang sangat sederhana sekali. Hal ini tak usah kita permasalahkan apalagi sampai kemudian mengatakan hal-hal yang tidak baik dengan apa yang terjadi di masa itu. System pembelajaran yang sederhana itu memang dilakukan dengan cara yang mudah agar para murid dengan bebas dan leluasa mengikuti proses pembelajaran Pendidikan agama Islam (Rahmani et al., 2020, p. 9).

\section{Kuttab di Zaman Nabi}

Pada zaman Nabi Muhammad SAW belum ada lembaga pendidikan secara formal yang dapat diidentifikasi keberadaanya. Namun sejak awal kedatangannya Islam, pada periode Madinahlah kemudian muncul lembaga pendidikan Islam yang bernama kuttab yang ini nantinya akan menjadi prototype sistem pendidikan formal di periode berikutnya (madrasah) (Novianti Muspiroh, 2019, p. 169). Kuttab muncul kembali di zaman Nabi akibat dari banyaknya antusias masyarakat saat itu yang ingin belajar serta dilakukan oleh Nabi untuk memberantas buta huruf di kalangan masyarakat tak terkecuali anak-anak (Zuhairini, Moh. Kasiram, Abdul Ghofir, Tajdab, 2013, p. 57). Selain alasan tersebut, kuttab di zaman Nabi dibangun di samping masjid dengan tujuan agar kekahawatiran orang-orang dewasa akan anak-anak yang mengotori masjid dapat teratasi dengan baik (Kodir, 2015). Meski keberadaannya sudah ada sejak Islam belum lahir, namun eksistensi kuttab di zaman Nabi pada periode Madinah ini telah mendapat perhatian yang serius dari Nabi Muhammad SAW (Husin, 2017, p. 78).

Dalam rangka menyiapkan generasi yang unggul di masa yang akan datang agar dapat menerima warisan Islam dan bertanggungjawab atas keberlangsungan untuk selalu mengemban amanah misi dakwah, maka Nabi telah mengeluarkan kebijakan kepada anak-anak sejak kecil agar diperintahkan untuk belajar membaca dan menulis, serta membaca dan menghafal alQur'an. Hal ini kemudian Nabi memberikan sebuah janji kebebasan bagi tawanan perang badar yang pandai baca-tulis agar dapat menebus dirinya dan boleh kembali ke negerinya jika setelah 
selesai mengajarkan baca-tulis kepada 10 orang anak Madinah (Zuhairini, Moh. Kasiram, Abdul Ghofir, Tajdab, 2013, p. 89). Dengan cara inilah lembaga kuttab yang awalnya tidak mendapatkan perhatian dari bangsa Arab kemudian di manfaatkan oleh Nabi sebagai tempat proses pembelajaran (Badriah, 2015, p. 164).

Selain dari tawanan perang Badar, Nabi juga memerintahkan Al-Hakam bin Sa'id untuk mengajar pada sebuah kuttab di Madinah. Ini menunjukkan bahwa pendidikan telah menjadi perhatian utama umat Islam sejak masa yang paling awal (Rahmani et al., 2020, p. 11).

Dikatakan sebagai lembaga pendidikan dasar maka sudah barang tentu kurikulum atau materi yang diajarkan adalah tentang membaca, menulis dan mempelajari al-Qur'an serta dasardasar ajaran Islam (Kodir, 2015, p. 44), di kuttab ini juga dikatakan sebagai pusat Pendidikan untuk membaca dan menulis (Mashuri, 2007, p. 231). Juga mempelajari syair-syair yang terkenal di masanya (Zuhairini, Moh. Kasiram, Abdul Ghofir, Tajdab, 2013, p. 90). Mengajar keterampilan membaca dan menulis dilakukan oleh guru-guru yang mengajar secara sukarela (Abuddin Nata, 2014, p. 98).

\section{Kuttab di Zaman Khulafaur Rasyidin}

Secara kelembagaan, kuttab di zaman Khulafaur Rasyidin ini melanjutkan dari apa yang pernah ada pada masa Nabi. Tidak ada begitu banyak hal yang signifikan atau berubah dari periode sebelumnya kecuali penambahan kurikulum di dalamnya (Fajriah, 2019, p. 120).

Kurikulum, terkait dengan materi yang diajarkan di kuttab pada masa khalifah Abu Bakar adalah terkait tentang membaca dan menulis, membaca al-Qur'an dan menghafalnya, serta pokok-pokok agama Islam seperti ibadah, akhlak dan muamalah. Hal ini sedikit berbeda dengan apa yang terjadi ketika di zaman khalifah Umar bin Khattab, materi pendidikan ditambahkan lagi seperti berenang, mengendarai onta, memanah, membaca/menghafal syair-syair yang mudah dan juga peribahasa. Penambahan materi yang ada pada zaman Umar ini tentu sedikit berbeda jika dibandingkan dengan periode sebelumnya, pada masa khalifah Abu Bakar. Kondisi sosial-politik yang aman dan stabil, membuat perkembangan lembaga pendidikan semakin lebih baik lagi jika dilihat dari sisi kurikulumnya. Di masa khalifah Utsman bin Affan, tidak begitu banyak perkembangan pendidikan Islam. Semuanya adalah meneruskan dari apa yang telah berjalan dengan baik dari periode sebelumnya. Namun meski demikian, pada masa khalifah Utsman ini terdapat sebuah kebijakan yang mewarnai pendidikan Islam yakni para sahabat yang berpengaruh dan dekat dengan Rasulullah diberikan kelonggaran untuk keluar dan menetap di daerah yang mereka sukai. Akibat kebijakan ini, pendidikan Islam lebih merakyat dan dapat dijangkau oleh seluruh lapisan masyarakat karena banyaknya para sahabat yang menyebar di tiap-tiap daerah di masing-masing pusat pendidikan yang ditinggalinya. Oleh karena itu pada masa inilah yang menurut penulis merupakan awal dari penyebaran pendidikan Islam secara massif guna memperluas dakwah Islamiyah di seluruh penjuru daerah. Berikutnya adalah pada masa khalifah Ali bin Abi Thalib, tidak banyak terjadi perkembangan kurikulum pendidikannya. Hal ini terjadi karena situasi politik yang kacau dan banyak pemberontakan. Walhasil pada periode ini tidak ada perkembangan yang berarti di bidang pendidikan Islam (Ramayulis, 2011, p. 62).

\section{Kuttab di Zaman Dinasti Umayyah}

Kemajuan Pendidikan islam pada masa dinasti Umayyah ini sebenarnya adalah erat kaitannya dengan situasi politik yang aman dan stabil. Bagaimanapun juga meski politik dan 
pendidikan itu merupakan dua hal yang berbeda, namun pada kenyataannya kondisi politik pada pemerintahan yang nyaman ini dapat mempengaruhi berbagai kebijakan di bidang pendidikan. Hal ini terbukti bahwa dengan stabilnya suasana politik saat itu, telah menghadirkan beberapa perkembangan Pendidikan islam dan telah melahirkan banyak tokoh-tokoh ilmu pengetahuan di bidangnya masing-masing (Niswah, 2017, p. 183).

Sebenarnya kuttab telah ada sejak periode sebelumnya, yakni pada masa Khulafaur Rasyidin. Akan tetapi pelaksanaan pembelajaran di lembaga pendidikan ini (kuttab) dilaksanakan di dekat masjid dan biasanya gurunya tidak dibayar. Pada masa Nabi dan Khulafaur Rasyidin, biasanya kuttab berada di samping masjid (Kodir, 2015, p. 45) namun pada masa khalifah Muawiyah, kuttab tidak hanya di dekat masjid namun juga di rumah guru dan di istana. Bagi guru kutab yang mengajar di masjid, memanglah guru tidak diberi gaji, namun guru kuttab yang di istana diberi gaji, bahkan sebagian khalifah telah menyediakan tempat mukim untuk guru di istana (Ramayulis, 2011, p. 71).

Kurikulum atau materi yang diajarkan di kuttab pada periode dinasti Umayyah ini adalah tentang al-Qur'an, hadits, syair-syair, riwayat hukama, membaca, menulis, dan berhitung. Artinya kurikulum yang dipakai ini bukan saja mengajarkan tentang ilmu pengetahuan umum, namun juga mengajarkan tentang kecerdasan, jiwa dan raga anak (Abudin Nata, 2014, p. 134). Untuk memperkaya dan dijadikan sebagai kurikulum tambahan, kadang di lembaga ini juga diajarkan tentang ilmu nahwu, ilmu bahasa dan ilmu arudh sebagai bekal Ketika para peserta didik sudah tamat dari kuttab (Permana, 2018, p. 47).

Tidak banyak yang ditemui terkait dengan peradaban yang ada pada dinasti Umayyah, karena memang pada masa ini gerakan-gerakannya lebih focus pada ekspansi atau perluasan wilayah daripada membangun sebuah peradaban yang maju. Hal ini berbanding terbalik dengan apa yang terjadi pada dinasti berikutnya yakni dinasti Abbasiyah, yang getol dengan perhatian terhadap ilmu pengetahuan dan peradaban Islam, tak ayal jika pada masa itu Islam telah mencapai puncak kejayaannya. Meski demikian pada dinasti Umayyah juga tidak menafikan sama sekali, ilmu pengetahuan juga menjadi perhatian meski dalam jumlah porsi yang tidak begitu besar jika dibandingkan dengan apa yang terjadi pada masa dinasti Abbasiyah (Serli Mahroes, 2015, p. 84). Hal ini dapat dibuktikan bahwa meski dalam porsi yang kecil, Pada masa pemerintahan Umar bin Abdul Aziz ternyata mengutamakan pembangunan-pembangunan dalam negeri. Karena menurutnya dengan memperbaiki dan meningkatkan kesejahteraan negeri-negeri Islam adalah lebih baik dari pada menambah perluasan wilayah atau ekspansi (Muslim \& Afdayeni, 2019, p. 34).

\section{Kuttab di Zaman Dinasti Abbasiyah}

Kuttab pada masa ini merupakan kelanjutan dari kuttab pada masa dinasti Umayyah sebelumnya. Sebagai lembaga pendidikan dasar maka yang diajarkan adalah tentang membaca dan menulis, al-Qur'an, kaligrafi, gramatikal bahasa Arab, matematika dan sejarah (Ramayulis, 2011, p. 77). Hal ini sebagaimana dibenarkan oleh Phillip K. Hitty yang menjekaskan bahwa kurikulum utama di kuttab adalah dipusatkan pada al-Qur'an sebagai bacaan utama para murid, dan juga diajari ketrampilan baca-tulis (Phillip. K. Hitti, 2002, p. 512).

Pada masa ini sebenarnya keberadaan kuttab terdapat apada ruangan di tempat guru, namun seiring dengan berjalannya waktu dan banyak umat islam yang ingin belajar baca-tulis, maka didirikanlah kuttab di sudut-sudut masjid atau ruangan yang masih berhubungan dengan 
masjid. Namun lambat laun kondisi yang demikian ini telah berubah, kuttab telah berdiri terpisah dari masjid (Zakirah et al., 2020, p. 2).

Sebagai lembaga pendidikan yang bersifat nonformal (Ifendi, 2020a, p. 156), pembiayaan kuttab berasal dari anggaran belanja pemerintah serta dana dari wakaf yang berhasil dihimpun. Dana tersebut digunakan untuk biaya hidup para guru, para pelajar, pembangunan gedung tempat belajar, pengadaan sarana dan prasarana serta peralatan pendidikan lainnya (Abudin Nata, 2014, p. 175). Kaitannya dengan sarana dan prasarana maka sebenarnya kelengkapan sarana dan prasarana yang baik dan komplit juga dapat dikatakan sebagai ujung tombak keberhasilan dalam mengelola Lembaga Pendidikan Islam. Meskipun tidaklah menjadi sebuah keharusan, jika dalam kondisi yang terbatas, menggunakan sarana dan prasarana apa adanya tentu akan menjadi sebuah upaya keberhasilan di lain sisi. Bagaimanapun juga etos belajar yang tinggi, meski dalam keadaan yang serba terbatas, insya Allah akan menopang keberhasilan juga (Novita, 2017, p. 97).

Pada masa pemerintahan Daulah Abbasiyah, kuttab tidak hanya sebagai pendidikan dasar namun juga menjadi tempat belajar bagi pendidikan menegah dan tingkat tinggi. Hal ini berbeda dengan keberadaan pada masa sebelumnya yang fungsinya sebagai tempat memberikan pelajaran menulis dan membaca bagi anak-anak atau lembaga pendidikan dasar (Zakirah et al., 2020, p. 6). Oleh karena itu di level menengah dan pendidikan tinggi konten kurikulumnya pun tentunya berbeda dengan apa yang ada di pendidikan dasar. Adapun kurikulumnya pada tingkat menengah meliputi: Al-qur'an, bahasa Arab dan kesusastraannya, fiqh, tafsir, hadis, nahwu/saraf, balagah, ilmu-ilmu pasti, mantiq, falak, tarikh, ilmu-ilmu alam, kedokteran, musik. Sedangkan untuk rencana pelajaran pada tingkat tinggi meliputi : tafsir Al-qur'an, hadis, fiqh, dan ushul fiqh, nahwu/saraf, balagah, bahasa Arab dan kesusasteraannya. Ada juga mantiq, ilmu-ilmu alam dan kimia, musik, ilmu-ilmu pasti, ilmu ukur, falak, ilahiyah (ketuhanan), ilmu hewan, ilmu tumbuhtumbuhan, kedokteran (Zakirah et al., 2020, p. 6).

Pendidikan di Kuttab terlihat cukup demokratis dengan memberikan perlakuan yang sama pada pelajar laki-laki dan perempuan. Pada masa dinasti Abbasiyah, peserta didik memiliki kesempatan untuk memilih materi pelajaran pilihan yang disenanginya. Hubungan guru dan peserta didik di Kuttab adalah seperti hubungan orang tua dengan anak-anak kandungnya sendiri. Mereka mengajar dengan berbagai metode (seperti metode ceramah, dikte, membaca, diskusi, simulasi, dll) dan pendekatan yang simulasi, dll) dan pendekatan yang tradisional dan kontekstual (Batubara \& Ariani, 2016, p. 98). Hal senada juga diungkapkan oleh Farid Permana bahwa di dalam kuttab, para guru yang merupakan ulama atau setidaknya orang yang ahli dalam membaca Al-qur'an tidak membedakan murid-murid mereka, bahkan ada sebagian anak miskin yang belajar di Kuttab memperoleh pakaian dan makanan secara gratis. Anak-anak perempuan pun memperoleh hak yang sama dengan anak-anak laki-laki dalam belajar. Hal ini merupakan sebuah bukti nyata tentang demokratisasi Pendidikan Islam yang juga harus kita jaga dan diterapkan sepanjang masa (Permana, 2018, p. 50).

Di bawah ini akan penulis sajikan perkembangan kuttab dari masa ke masa beserta dengan pembaruan kurikulum dan pembiayaannya: 
Tabel. 1. Karakteristik Kuttab di setiap periode

\begin{tabular}{|c|c|c|}
\hline Periode & Kurikulum & Pembiayaan \\
\hline $\begin{array}{l}\text { Nabi Muhammad } \\
\text { Saw }\end{array}$ & $\begin{array}{l}\text { Membaca dan menulis, al-Qur'an, Syair- } \\
\text { syair }\end{array}$ & Sukarela \\
\hline $\begin{array}{l}\text { Khulafaur } \\
\text { Rasyidin }\end{array}$ & $\begin{array}{l}\text { Baca-tulis, al-Qur'an, dasar-dasar ajaran } \\
\text { Islam, berenang, mengendarai onta, } \\
\text { memanah, membaca/menghafal syair- } \\
\text { syair yang mudah dan juga peribahasa }\end{array}$ & Pajak tanah \\
\hline Dinasti Umayyah & $\begin{array}{l}\text { Al-Qur'an, hadits, syair-syair, riwayat } \\
\text { hukama, membaca, menulis, dan } \\
\text { berhitung. Artinya kurikulum yang } \\
\text { dipakai ini bukan saja mengajarkan } \\
\text { tentang ilmu pengetahuan umum, namun } \\
\text { juga mengajarkan tentang kecerdasan, } \\
\text { jiwa dan raga anak. }\end{array}$ & $\begin{array}{l}\text { Tidak dijumpai. Namun } \\
\text { secara umum pastilah para } \\
\text { khalifah mengeluarkan } \\
\text { biaya untuk masalah } \\
\text { pendidikan }\end{array}$ \\
\hline Dinasti Abbasiyah & $\begin{array}{l}\text { Membaca dan menulis, al-Qur'an, } \\
\text { kaligrafi, gramatikal bahasa Arab, } \\
\text { matematika dan sejarah }\end{array}$ & $\begin{array}{l}\text { Anggaran belanja negara } \\
\text { dan wakaf }\end{array}$ \\
\hline
\end{tabular}

Pada umumnya metode pembelajaran yang diapakai adalah metode yang sesuai dengan fitrah manusia sebagai makhluk yang memiliki berbagai kecenderungan, kekurangan dan kelebihan. Oleh karena itu berbagai metode pembelajaran digunakan di kuttab seperti metode ceramah, diskusi, musyawarah, tanya jawab, bimbingan, teladan, demonstrasi, hafalan, bercerita dan penugasan (Abudin Nata, 2014, p. 96).

\section{Analisis Historis Kuttab}

Melihat data sejarah yang telah ada dipapakan di atas, hal ini dapat ditarik sebuah kesimpulan bahwa:

Pertama, kuttab sebagai pusat pendidikan dasar (baca-tulis) untuk anak-anak (Badriah, 2015, p. 165) telah ada sejak zaman Nabi, bahkan sebelum Islam datang (pra Islam) hal ini dibuktikan dengan adanya 17 orang dari Quraisy yang pandai baca-tulis. Namun dalam perjalanannya, kuttab ini kurang berkembang dan tidak banyak mengalami kemajuan.

Kedua, sebagai lembaga pendidikan Islam dasar, bahkan ada yang mengatakan sebagai lembaga pendidikan dasar yang pertama dalam dunia Islam (Rahmani et al., 2020, p. 8) kuttab tentu menjadi sebuah institusi yang sangat penting. Bagaimana tidak? Keberadaan tulis-menulis dan membaca tentu akan menjadi hal yang sangat dibutuhkan seiring dengan berjalannya waktu. Lahirnya para sahabat yang pandai baca-tulis, tentu akan semakin menguatkan Islam berkaitan dengan administrasinya. Catatan wahyu yang ditulis oleh sahabat Zaid bin Tsabit juga berangkat dari budaya tulis-menulis. Bisa dibayangkan jika saat itu tulis-menulis tidak ada, maka umat islam akan semakin sulit untuk dapat mempelajari agama dari sumbernya (Al-Qur'an dan hadits). Dan juga bisa dikatakan bahwa kuttab ini berperan dalam membangun semangat literasi untuk masyarakat secara umum di awal-awal Islam (Novianti Muspiroh, 2019, p. 169). Dalam perjalanannya, kuttab menempati posisi yang sangat penting dalam pengajaran Al-qur'an, sebab 
menghafal Al-qur'an menjadi tradisi yang mendapatkan kedudukan terhormat di kalangan pemimpin dan umat Islam (Andriani, 2016, p. 332).

Ketiga, beragamnya kurikulum yang ada di kuttab ini menunjukkan bahwa materi yang diajarkan bersifat dinamis sesuai dengan kondisi zamannya. Apa yang diajarkan pada masa Nabi, tentu akan sedikit berbeda dengan apa yang diajarkan pada masa berikutnya. Hal ini terjadi tak lain dan tak bukan karena memang perubahan zaman mengharuskan kita untuk selalu adaptif teradap segala sesuatu yang dibutuhkan secara insidental. Hal ini juga dapat dipengaruhi oleh geografis di wilayah tertentu, dan juga oleh pengajarnya sendiri yang menginginkan pola atau konsep pendidikan kuttab yang berbeda dengan yang lainnya. Perubahan-perubahan terhadap kurikulum Pendidikan Islam ini memang sebuah keharusan, karena bagaimanapun juga dunia telah berubah, zaman dari zaman telah bergeser dan menuntut sebuah keharusan yang berbeda pula. Walhasil, berkembangnya kurikulum yang ada pada Lembaga kuttab ini tentu akan sesuai dengan kebutuhan dan permintaan pasar di masanya. Seperti dewasa ini, kurikulum Pendidikan Islam harus disesuaikan dengan tuntutan dan tantangan zaman yang semakin hari semakin komptitif, yang mengharuskan para lulusannya untuk sigap dan tanggap terhadap segala jenis perubahan yang setiap saat terjadi.

Keempat, perkembangan kuttab dari masa ke masa menunjukkan perkembangan ke arah yang lebih baik. Secara pengelolaan, kuttab di masa dinasti Abbasiyah lebih terstruktur dan berjalan secara formal. Bahkan kuttab tidak hanya sebagai lembaga pendidikan Islam dasar namun juga ada tingkat menengah dan tinggi. Ini berarti kuttab tidak terbentuk dalam waktu yang sebentar. Namun rentang waktu sejarah yang panjang dari masa kenabian hingga sampai dinasti Abbasiyah merupakan sebuah proses transformasi institusi Islam yang bertujuan untuk mendidik putra-putri umat Islam secara keseluruhan untuk mencetak generasi Islam yang beriman dan bertaqwa kepada Allah SWT, unggul, beradab dan berdaya saing (Yusnadi \& Fakhrurrazi, 2020, p. 168). Kemajuan sains dan teknologi berdampak serius pada kehidupan manusia. Begitu banyak efek negatif dampak dari globalisasi dan krisis lingkungan hidup yang harus dihadapi oleh umat Muslim. Oleh karena itu, pendidikan Islam melalui beragam institusinya seperti kuttab inilah harus mampu membangun generasi Muslim yang tangguh melalui pendidikan Islam yang bermutu dan berkualitas (Tidjani, 2017, p. 96). Selain itu bagaimanapun juga dalam keadaan apapun itu, Pendidikan islam harus mampu mendorong dan membentuk generasi ini untuk menjadi genarasi yang berkarakter, selalu berpikir positif, memiliki akhlak di setiap tutur kata dan perilakunya yang dapat diimplementasikan dalam kehidupan sehari-hari (Asmaun Sahlan, 2012, p. 146).

Kelima, sebagai institusi Pendidikan dasar yang memiliki ciri khas keislaman, maka sudah barang tentu kita semua dapat meniru, mengamati dan memodifikasi apa yang terdapat di dalam institusi islam ini. Baik yang berhubungan dengan system pembelajarannya, kurikulum, pembiayaan, sarana dan prasarana, serta berbagai hal lainnya yang dapat kita implementasikan pada kehidupan dewasa ini. Dari sinilah kemudian kita dapat berfikir bahwa sebagai lembaga Pendidikan Islam, harus selalu berusaha dan berupaya untuk memberikan yang terbaik kepada para pengguna dan harus meningkatkan kualitas mutunya. Lembaga Pendidikan Islam seperti kuttab ini tidak boleh kalah dengan Lembaga Pendidikan lain yang lebih mengedepankan Pendidikan umum (Umar \& Ismail, 2018, p. 1). 


\section{KESIMPULAN}

Kuttab berperan penting dalam pendidikan Islam karena pada institusi dasar ini diajarkan bagaimana tata cara menulis, membaca dan memahami al-Qur'an. Hal ini dikarenakan al-Qur'an merupakan wahyu Illahi yang berfungsi sebagai sumber ilmu pengetahuan. Seseorang yang memiliki pemahaman terhadap al-Qur'an adalah sebaik-baiknya orang, karena ia adalah orang yang telah memahami hakikat ilmu pengetahuan.

Meskipun di setiap periode memiliki beberapa kesamaan dan perbedaan latar munculnya lembaga pendidikan ini, kuttab tetaplah sebuah lembaga pendidikan Islam yang menjadi prototype pendidikan dewasa ini. Pun beragamnya kurikulum atau materi ajar di dalamnya, meski ada perbedaan antara kuttab satu dengan kuttab lainnya yang terletak pada penekanan materi pembelajaran karena disesuiakan dengan kebutuhan daerah masing-masing dan pertimbangan guru pengajarnya. Meskipun demikian, secara inti bahwa kuttab ditujukan kepada anak-anak muslim terhadap ilmu membaca, menulis al-Qur'an serta prinsip-prinsip ajaran dasar tentang Islam.

\section{DAFTAR PUSTAKA}

Abuddin Nata. (2014). Sejarah Pendidikan Islam (II). Prenadamedia Group, Divisi Kencana.

Andriani, A. (2016). Munculnya Lembaga Pendidikan Islam. FALASIFA: Jurnal Studi Keislaman, 7(2), 285-298.

Arifin, M. (2014). Ilmu Pendidikan Islam: Tinjauan Teoretis dan Praktis Berdasarkan Pendekatan Interdisipliner (IV). Bumi Aksara.

Asmaun Sahlan. (2012). Pendidikan Karakter dalam Perspektif Islam (Kajian Penerapan Pendidikan Karakter di Lembaga Pendidikan Islam). Jurnal El-Hikmah, Vol IX(02), 139149.

Badriah, L. (2015). Kurikulum Pendidikan Islam Masa Klasik. LITERASI (Jurnal Ilmu Pendidikan), 6(2), 155. https://doi.org/10.21927/literasi.2015.6(2).155-176

Batubara, H. H., \& Ariani, D. N. (2016). Kuttab sebagai Potret Pendidikan Dasar Periode Klasik. Muallimuna: Jurnal Madrasah $\quad$ Ibtidaiyah, $\quad 1(2), \quad 98$. https://doi.org/10.31602/muallimuna.v1i2.388

Darwis, D. (2010). Dinamika Pendidikan Islam : Sejarah, Ragam dan Kelembagaan. RaSAIL.

Fajriah, N. (2019). Gambaran Sistem Pendidikan Islam pada Masa Sahabat. Jurnal Serambi Ilmu, 20(1), 120-136.

Fathurrahman. (2017). Eksistensi Kuttab dan Masjid Sebagai Institusi Pendidikan Pada Masa Pertumbuhan Islam. Kreatif, XIV(1), 56-74.

Hawi, A. (2017). Tantangan Lembaga Pendidikan Islam. Tadrib, 3(1), 144-161.

Husin, G. I. (2017). Pendidikan Islam Di Masa Rasulullah Pada Periode Mekkah dan Periode Madinah. Jurnal Ilmiah Al QALAM, 11(24), 69-88.

Ifendi, M. (2020a). Dinasti Abbasiyah: Studi Analisis Lembaga Pendidikan Islam. Fenomena, $12(2), 139-160$.

Ifendi, M. (2020b). Masa Pembinaan Pendidikan Islam: Telaah Kritis Pendidikan Rasulullah SAW Pada Periode Makkah. Al-Rabwah, XIV(1), 58-74. 
Kaelan. (2010). Metode Penelitian Agama Kualitatif Interdisipliner. Paradigma.

Kodir, A. (2015). Sejarah Pendidikan Islam: dari Masa Rasulullah hingga Reformasi di Indonesia.

Laisa, E. (2020). Kuttab Sebagai Pusat Ilmu Pengetahuan Pendidikan Islam. Rabbani: Jurnal Pendidikan Agama Islam, 1(September), 94-112.

Mashuri, S. (2007). Transformasi Tradisi Keilmuan Dalam Islam: Melacak Akar Kemunculan Dan Perkembangan Institusi Pendidikan Islam. Journal Hunafa, 04(03), 227-237.

Matthew B. Miles, A. Michael Huberman, J. S. (2014). Qualitative Data Analysis: A Methods Sourcebook (third). SAGE Publications Ltd. http://library1.nida.ac.th/termpaper6/sd/2554/19755.pdf

Muslim, K. L., \& Afdayeni, M. (2019). Umar Bin Abdul Azis: Zaman Keemasan Islam Masa Dinasti Umayyah. Islam Transformatif: Journal of Islamic Studies, 3(1), 30. https://doi.org/10.30983/it.v3i1.797

Niswah, C. (2017). Pendidikan Islam pada Masa Khulafa Al-Rasyidin dan Bani Umayyah. Tadrib: Jurnal Pendidikan Agama Islam, 1(2), 170-185.

Novianti Muspiroh. (2019). Kuttab Sebagai Pendidikan Dasar Islam dan Peletak Dasar Literasi. Tamaddun, 7(1), 169-192.

Novita, M. (2017). Sarana Dan Prasarana Yang Baik Menjadi Bagian Ujung Tombak Keberhasilan Lembaga Pendidikan Islam. NUR EL-ISLAM : Jurnal Pendidikan Dan Sosial Keagamaan, 4(2), 102-103.

Permana, F. (2018). Pendidikan Islam Dan Pengajaran Bahasa Arab Pada Masa Dinasti Umayyah. Al Qalam: Jurnal Ilmiah Keagamaan Dan Kemasyarakatan, 12(2), 47. https://doi.org/10.35931/aq.v0i0.74

Phillip. K. Hitti. (2002). Terjemahan History of the Arabs. Serambi Ilmu Semesta.

Rahmani, M., Fatimah, S., Berampu, N., \& Lubis, F. K. (2020). Mengenal Lembaga Pendidikan Dasar Kuttab Periode Klasik. AL-ULUM : JURNAL PENDIDIKAN ISLAM, 01(01), 8-17.

Ramayulis. (2011). Sejarah Pendidikan Islam: Napaktilas Perubahan Konsep, Filsafat, dan Metodologi Pendidikan Islam dari Era Nabi SAW sampai Ulama Nusantara (Cet. 1). Kalam Mulia.

Roqib, M. (2009). Ilmu pendidikan Islam. LKiS.

Serli Mahroes. (2015). Kebangkitan Pendidikan Bani Abbasiyah Perspektif Sejarah Pendidikan Islam. TARBIYA: Jurnal Ilmu Pendidikan Islam, 01(01), 77-108.

Soraya, N. (2016). Lembaga Pendidikan Islam Periode Awal dalam Perspektif Sejarah. Tadrib. http://jurnal.radenfatah.ac.id/index.php/Tadrib/article/view/1171

Tidjani, A. (2017). Manajemen Lembaga Pendidikan Islam Menghadapi Tantangan Globalisasi. Jurnal Reflektika, 13(1), 96-126.

Umar, M., \& Ismail, F. (2018). Peningkatan Mutu Lembaga Pendidikan Islam (Tinjauan Konsep Mutu Edward Deming dan Joseph Juran). Jurnal Ilmiah Iqra', 11(2). https://doi.org/10.30984/jii.v11i2.581

Yasin, A. F. (2008). Dimensi-dimensi Pendidikan Islam (A. Barizi (ed.); 1st ed.). UIN-Malang Press. 
Yusnadi, Y., \& Fakhrurrazi, F. (2020). Pendidikan Islam Pada Masa Daulah Bani Umayyah. AtTa'dib: Jurnal Ilmiah Prodi Pendidikan Agama Islam, 163. https://doi.org/10.47498/tadib.v12i02.383

Zainal Aqib. (2014). Manajemen Lembaga Pendidikan Islam. Sarana Tutorial Nurani Sejahtera.

Zakirah, Z., Arsyam, M., Herianto, H., \& Umar, K. (2020). Pendidikan Dasar (Kuttab) Masa Daulah Abbasiyah (132-232 H / 750-847 M). 1-16.

Zuhairini, Moh. Kasiram, Abdul Ghofir, Tajdab, M. F. dan M. U. (2013). Sejarah Pendidikan Islam (XII). Bumi Aksara. 